\title{
PELATIHAN PENGEMBANGAN MINAT DAN POTENSI GURU DALAM PENULISAN KARYA TULIS ILMIAH DI MADRASAH ALIYAH MIFTAHUL ISHLAH TEMBELOK KOTA MATARAM TAHUN 2018
}

\author{
Baehaqi \\ Universitas Islam Negeri Mataram \\ baehaqiyazid68@gmail.com
}

\begin{abstract}
Abstrak: Masalah dalam dunia pendidikan hususnya dalam pendidkan pormal, khususnya di Madrasah Aliyah Miftahul Ishlah adalah kegiatan pendidikan masih terpasung dalam persoalan didaktika atau persoalan peroses pembelajaran. Akibatnya, esensi pendidikan yaitu pengembangan ilmu pengetahuan menjadi terabaikan. Kegiatan pengabdian ini bertujuan untuk mengembangkan profesioalisme guru sehingga mutu pendidikan meningkat. Kegiatan ini sekaligus sebagai sarana mendekatkan lembaga pendidikan tinggi dalam hal ini Universitas Islam Negeri (UIN) mataram dengan masyarakat. Hal ini merupakan salah satu unsur dari Tri Darma perguruan tinggi, sehingga perguruan tinggi dapat memberdayakan masyarakat dan mempersiapkan generasi yang berkualitas dalam tataran pengetahuan, agama, dan moral. Metode yang digunakan dalam kegiatan pengabdian ini adalah Participatory Action Research (PAR) yang bertujuan untuk melibatkan para guru sebagai peserta aktif pelatihan sehingga dapat mendorong tumbuhnya minat mereka dalam menulis karya ilmiah setelah selesai pelatihan. Hasil dari pelatihan ini adalah tumbuhnya minat guru dalam menulis karya ilmiah dan tersusunnya sebuah karya tulis ilmiah berupa buku sederhana.
\end{abstract}

Kata Kunci: pengembangan, minat dan potensi, karya tulis ilmiah

\begin{abstract}
The problem in the formal education, especially in the Madrasah Aliyah Miftahul Ishlah is that educational activities are still attached to inactic problems or learning process problems. As a result, the essence of education, namely the development of science, was neglected. This community service program aims to develop teacher professionalism so that the quality of education increases. This program is also a means of bringing higher education institutions closer together in this case the Mataram State Islamic University (UIN) with the community. It is one of the elements of higher education mandate, so that universities can empower the community and prepare a generation at the level of knowledge, religion and morals. The method used is Participatory Action Research (PAR), which aims to involve the teachers as active participants in the training so that they can encourage the growth of their interest in writing scientific work after the training is finished. The results of this training were the growing interest of teachers in writing scientific papers and the compilation of a scientific paper in the form of a simple book.
\end{abstract}

Keywords: development, interest and potential, scientific papers

\section{Pendahuluan}

Selama ini pendidikan, tak terkecuali pendidikan Islam, cenderung dimaknai dan dipraktikkan lebih sebagai instrumen keilmuan daripada sebagai sebuah entitas keilmuan ${ }^{1}$. Tak pelak aktivitas pendidikan pun dijalankan terutama sebagai praktik pembelajaran ketimbang pengayaan keilmuan. Hal ini tampaknya juga mewarnai pola paradigmatik dari pelaksanaan

1 Pemaknaan sedemikian jelas problematis karena secara filosofis pendidikan adalah ikhtiar pemanusiaan manusia dan karena itu sepatutnya ia tidak diperlakukan sebatas intrumen keilmuan melainkan benar-benar sebagai entitas keilmuan. Lihat dan bdk. dengan Terence W. Moore, Philosophy of Education: An Introduction (London: Routledge \&Kegan Paul, 2010), 11-14. 
aneka program pembinaan institusi-institusi pendidikan Islam semisal madrasah, tak terkecuali seperti yang selama ini dihelat Universitas Islam Negeri (UIN) Mataram.

Dalam hal itu pemberdayaan institusi pendidikan cenderung berlangsung dalam skema rutin, yakni berkutat di seputar desain dan praktik pembelajaran, metode pembelajaran, pengayaan kurikulum, penguatan managemen atau bahkan sekedar upgrading administrasi kependidikan, dan semacamnya ${ }^{2}$. Sementara praksis pendidikan sendiri berlangsung dengan logika senada, yakni terlalu berfokus pada penguatan sisi kognitif dan juga afektif, sedangkan sisi pengayaan keterampilan—dalam hal ini menulis karya ilmiah—cenderung dialfakan.

Pengembangan keterampilan menulis memang nyaris terabaikan dalam praksis pendidikan mutakhir, padahal menulis adalah dimensi niscaya dari kreativitas yang sangatlah penting bagi pengembangan keilmuan di samping membaca dan diskusi (dialog) ${ }^{3}$.Ironisnya, pengabaian ini tidak hanya dialami para subjek didik, murid, tapi juga para pendidik (guru) mereka.

Guru sendiri kebanyakan lupa menggali potensi diri dalam hal menulis; mereka justru diasyikkan oleh tugas-tugas rutin pembelajaran sehingga semakin meredupkan minat mereka di bidang tulis-menulis ini.Pada gilirannya, guru tak ayal hanya sibuk mentransmisikan ilmu secara konvensional, yakni via lisan dengan waktu dan ruang (kelas) yang terbatas, sementara transferabilitas keilmuan ke konteks masyarakat luas melalui media tulisan nyaris tak tersentuh, bila bukan terlupakan sama sekali sebagai bagian dari komitmen intelektual mereka selaku pendidik haruslah meluangkan potensi, bakat, dan waktunya untuk membagi ilmunya melalaui tulisan. Di titik itu kepiawaian dan komitmen para guru dalam menulis karya ilmiah menjadi penting. Urgensinya terutama terkait peran fundamental mereka sebagai "guru kehidupan" kemana para subjek didik dan juga masyarakat luas menyandarkan sumber pengetahuannya. Guru adalah subjek aktif dalam pengembangan keilmuan sehingga pendidikan harus dimaknai sebagai praksis pengayaan keilmuan di mana keterampilan menulis mutlak dimiliki.

Berdasar logika pemaknaan dan kepentingan demikianlah pengabdian dengan cluster "Madrasah Binaan" ini dilaksanakan. Dengan memilih Madrasah Aliyah (MA) Miftahul Ishlah Tembelok Kota Mataram sebagai institusi dampingan, pengabdian ini mengambil fokus pada penumbuhan minat sekaligus penguatan potensi menulis karya ilmiah di kalangan guru. Pada gilirannya, melalui pilihan fokus tersebut, diharapkan ikhtiar pengabdian ini akan menuai signifikansi utamanya, yakni teretasnya kebangkitan tradisi menulis karya ilmiah di kalangan guru, teristimewa di lingkup institusi dampingan. Selanjutnya, diharapkan para guru akan menularkan keterampilan menulis itu pada para murid mereka sehingga praksis pendidikan betul-betul bermakna sebagai sebuah proses pengayaan keilmuan yang berkelanjutan.

Berdasarkan latar belakang masaalah diatas dapat dirumuskan masaalah sebagai berikut "Bagaimana cara menumbuhkan minat dan pontensi guru dalam penulisan karya ilmiyah di Madrasah Aliyah Miftahul Ishlah Tembelok" dari Rumusan Masalah ini akan dibahas berbagaimacam cara untuk menumbuhkan minat dan potensi menulis para guru.

\footnotetext{
2 Bdk. Abd. Rachman Assegaf, Filsafat Pendidikan Islam: Paradigma Baru Pendidikan Hadhari Berbasis Integratif-Interkonektif (Jakarta: RajaGrafindo Persada, 2011), 19-24.

${ }^{3}$ Logika kreativitas yang dilekatkan pada urgensi menulis di sini menimba inspirasi dari M. Taufik, Kreativitas: Jalan Baru Pendidikan Islam (Mataram: Leppim IAIN Mataram, 2012), 21-37.
} 
Adapun tujuan dari pengabdian Madrasah binaan adalah sebagai berikut: (1) Untuk menumbuhkan semangat para guru di madrasah tersebut untuk mengembangkan minat dan memperkuat potensi mereka dalam dunia tulis- menulis. (2) Untuk membangkitkan teradisi menulis di kalangan para guru MA Miftahul Ishlah Tembelok (3) terbekalinya keterampilan menulis pada para guru MA Miftahul Islah diharapkan dapat memotivasi mereka untuk mengaktifkan secara terus menerus (up date) laman atau website yang telah mereka punya.

Untuk mewujudkan tujuan dari pengabdian Madrasah Binaan ini , maka kegiatan ini tidak dapat dilakukan sendiri namun perlu melibatkan berbagai pihak. Para pihak yang terlibat dalam kegiatan pelatihan pengembangan minat dan potensi guru dalam penulisan karya ilmiah di MA. Miftahul Ishlah Tembelok. Terdapat sejumlah pihak yang terlibat (stake holders) dalam program pengabdian ini. Masing-masing pihak memiliki bentuk dan tingkat keterlibatannya sendiri. Dari seluruh pihak yang terlibat, para guru merupakan subjek utama dengan tingkat keterlibatan terbesar. Selain mereka, pihak lain yang dikehendaki terlibat adalah kepala madrasah, pengurus yayasan pesantren, dan tenaga kependidikan (para staf) di madrasah dampingan. Di luar pihak dari madrasah dampingan, program pengabdian ini juga melibatkan para narasumber yang berkompeten (experts) di bidang tulis- menulis dan, tentu saja, tim pengabdian sendiri yang berperan sebagai fasilitator.

Pilihan terhadap guru sebagai subjek atau stake holder utama program pengabdian ini bertolak dari satu postulat bahwa segala upaya peningkatan kualitas pendidikan haruslah dimulai dari peningkatan kualitas para tenaga pendidiknya ${ }^{4}$.Itulah mengapa program pengabdian ini terutama menyasar para guru mengingat mustahil meningkatkan kualitas pendidikan jika tidak dimulai dari meningkatkan kualitas para tenaga pendidiknya, termasuk kualitas dalam hal penguatan keterampilan mereka dalam penulisan karya ilmiah. Adapun keterlibatan kepala madrasah, pengurus yayasan, dan tenaga kependidikan lainnya dibutuhkan untuk turut membantu memetakan masalah-masalah umum kemadrasahan yang ditengarai mempengaruhi kualitas guru. Mereka terutama dilibatkan dalam pelaksanaan tahapan "persiapan sosial" dan "participatory assesment". Sementara narasumber ahli dibutuhkan khusus di tahap "melangsungkan aksi", tepatnya pada proses pelatihan penulisan karya ilmiah. Dalam hal ini mereka, minimal dua orang (praktisi jurnal ilmiah dan praktisi media massa), khusus membimbing para guru untuk memahami kiat-kiat menembus jurnal ilmiah dan media massa. Dalam keseluruhan proses itu, tim pengabdian terlibat penuh sebagai fasilitator dengan concern utama memastikan seluruh proses benar-benar mengantar pada pencapaian tujuan program.

\section{Metode}

Untuk mencapai atau mewujudkan tujuannya, program pengabdian ini dirancang dengan menerapkan suatu strategi pendampingan ${ }^{5}$. Dalam kerangka itu terdapat empat

\footnotetext{
${ }^{4}$ Postulat ini bertumpu pada peran "profetik" guru sebagai ujung tombak pendidikan. Lihat Suryadharma Ali, Mengawal Tradisi, Meraih Prestasi: Inovasi dan Aksi Pendidikan Islam (Malang: UIN-Maliki Press, 2013), 184-7.

5 Mengenai pengertian berikut operasionalisasinya, lihat Abdullah Faishol, dkk., Metode dan Teknik Kuliah Kerja Nyata Transformatif: Implementasi Participatory Action Research (PAR)\& Participatory Rural Appraisal (PRA) untuk Aksi Perubahan Sosial (Surakarta: P3M STAIN Surakarta, 2006), 117-26.
} 
tahapan strategis berpola circle, suatu proses dari refleksi ke aksi lalu ke refleksi terus ke aksi kembali demikian seterusnya, yang dijalankan secara bersama-sama dengan subjek dampingan. Berikut empat tahapan tersebut: Pertama, Persiapan Sosial. Tahapan ini meliputi antara lain sosialisasi program, komunikasi intensif, dialog kritis, dan interaksi produktif dengan pihak subjek dampingan. Dimaksudkan untuk menghindari miskomunikasi yang bisa berakibat pelaksanaan program tidak maksimal, atau malah penolakan. Tahap ini merupakan pintu masuk utama bagi pihak tim pengabdian untuk dapat merealisasikan program yang telah disepakati bersama dengan subjek dampingan (para guru MA Miftahul IslahTembelok).

Melalui tahapan ini diharapkan dapat terbangun keakraban sehingga pada gilirannya menumbuhkan saling percaya (trust) antarkedua pihak. Kemudian, kedua, Analisis Kebutuhan secara Partisipatif (participatory assesment). Dijalankan dengan melakukan pemetaan (mapping) terhadap kebutuhan dasar atau problem terkait fokus program yang dialami subjek dampingan. Melalui strategi ini, tim pengabdian bersama para subjek (komunitas) dampingan dapat menginventarisasi fakta-fakta problematis yang bersifat sosial (baca: problem sosial) dan bukan sebatas keluhan personal. Bentuk teknis dari penerapan strategi ini adalah pelangsungan focusedgroup discussion (FGD)dengan fokus pengabdian (Pengembangan minat dan potensi menulis karya ilmiah) sebaga tema bincang utamanya ${ }^{6}$. Ketiga, penyusunan program.

Tahapan ini dihelat dengan melangsungkan model FGD seperti di atas dengan agenda meliputi (1) analisis masalah dengan strategi perumusan pohon masalah, (2) analisis tujuan dengan strategi perumusan pohon tujuan, dan selanjutnya (3) penyusunan program kerja yang dituangkan dalam bentuk action plan. Dalam perumusan program kerja ini, subjek dampingan diposisikan sebagai penentu utama, sedangkan pihak tim pengabdian lebih memilih memainkan peran sebagai fasilitator bagi kepentingan mereka. Para subjek dampingan diandaikan tidak hanya berperan utama dalam penyusunan program kerja tapi sekaligus juga pelaku utama dalam tahap evaluasi dan melakukan kontrol penuh terhadap seluruh proses pengabdian. Hal ini dilakukan dengan semangat agar program pengabdian ini benarbenar sejalan dengan kepentingan dan kebutuhan dasar mereka terkait seputar peningkatan minat dan penguatan potensi mereka dalam penulisan karya ilmiah. Keempat, Melangsungkan Aksi (Sosial). Program kerja yang sudah disusun sistematis bersama subjek dampingan dan dituangkan dalam bentuk action plankemudian ditindaklanjuti dengan implementasi program. Dalam proses implementasi program itu subjek dampingan tetap memegang peran sebagai pelaku aktif, sedangkan tim pengabdian menahan diri untuk berlaku tetap sebagai fasilitator belaka dengan skema pendampingan. Pada tahap ini, aksi-aksi

\footnotetext{
${ }^{6}$ Selain itu, forum dikusi terfokus ini dilakukan juga untuk kepentingan klarifikasi atau konfirmasi sekaligus respons balik dari para stake holders (para peserta FGD; teristimewa subjek dampingan utama, yakni para guru MA Miftahul Islah) atas hasil temuan riset awal (prelimenaryresearch). Teknisnya, kepada semua peserta terlebih dahulu diberikan penjelasan tentang maksud dan tujuan diadakannya program pengabdian ini. Sesudah itu, peserta dibagi ke dalam beberapa kelompok untuk mendalami temuan masalah yang ada terkait fokus pengabdian yang belum mungkin sempat ditemukan oleh tim pengabdian. Hasil diskusi lalu diplenokan oleh wakil masing-masing kelompok. Segenap hasil temuan ini tentu belum final dan karena itu akan dipertajam kembali pada saat FGD sesi perumusan program kerja melalui matrix ranking,yakni analisis pohon masalah dan pohon tujuan
} 
pendidikan dan pelatihan penulisan karya ilmiah melalui pendekatan andragogis serta pendampingan berpola pembimbingan penulisan, misalnya klinik penulisan, secara intensif dilakukan dan difasilitasi oleh tim pengabdian sesuai dengan jenis program yang sudah disepakati bersama. Seluruh proses ini dikawal dengan cara pendampingan (asistensi) hingga hingga ke tahap penerbitan di jurnal ilmiah maupun media massa lokal atau tahap pengunggahan ( up load) di dunia maya. Terakhir, kelima, Monitoring, Evaluasi, dan Teoretisasi. Setiap pelaksanaanimplementasi program atau rancang aksi (sosial) itu senantiasa diiringi dengan tindakan refleksi dan evaluasi bersama;tahapan ini dilakukan secara bersama-sama antara subjek dampingan dan tim pengabdian selaku fasilitator atau pendamping. Dari hasil refleksi dan evaluasi inilah kemudian ditindaklanjuti kembali dengan melakukan aksi, tindakan reflektif. Lalu, dari aksi tersebut dilanjutkan dengan refleksi kembali yang kemudian diteruskan ke aksi lanjutan, demikian seterusnya hingga terjadi suatu perubahan produktif di diri subjek dampingan, yakni peningkatan minat dan penguatan potensi menulis karya ilmiah di kalangan guru MA Miftahul Ishlah.

\section{Hasil dan Pembahasan}

Karya Tulis Ilmiah memiliki peran sangat penting dan strategis dalam upaya pengembangan profesi guru, sebab terdapat hubungan yang saling mempengaruhi antara karya almiah yang dihasilkan guru dengan kualitas mengajar. Kualitas mengajar guru memang sangat dipengaruhi oleh upaya- upaya kreatif dan innovatif guru, kemudian diuji cobakan melelui proses eksperimen, dan akhirnya diterapkan dalam pembelajaran. Semakin sering seorang guru melakukan kegiatan-kegiatan ilmiah dan menghasilkan karya tulis ilmiah, maka semakin berkembang ilmu pengetahuannya sehingga akan semakin profesional.

Kegiatan-kegiatan ilmiah yang dilakukan seorang guru pasti melibatkan berbagai aktivitas seperti mengamati (observing), merumuskan sesuatu (questioning), mengasosiasikan (associating), mencoba/uji coba (eksperimenting), dan mengkomunikasikan (communicating). Selain hal tersebut seorang guru dalam kegiatan ilmiah ini (penelitian) pasti melacak, membaca, menulis, dan menganalisis literatur sehingga dari kegiatan ilmiah tersebut akan menambah, meningkatkan, bahkan menemukan pengetahuan baru bagi guru.

Kegiatan ilmiah ini sangat penting untuk meningkatkan mutu pembelajaran dan pedidikan. Guru sebagai komponen kunci dalam proses pembelajaran, perannya tidak dapat tergantikan, sehingga upaya meningkatkan mutu pendidikan harus dimulai dari mutu guru bahkan disebutkan "mutu pendidikan tidak pernah melebihi mutu gurunya" (the qualty of an education system cannot exceed the quality of its teacher). Dengan demikian, karena guru adalah bagian integral dari organisasi pendidikan di sekolah, maka agar sebuah organisasi sekolah/lembaga pendidikan mampu menghadapi perubahan dan terus meningkatkan dan mengembangkan kualitasnya maka perlunya menjadikan lembaga sekolah sebagai sebuah organisasi pembelajar.

Hal ini dapat dilakukan dengan mendorong guru baik secara individu maupun bersamasama dengan masyarakat seprofesinya untuk menjadi bagian dari organisasi pembelajar 
melalui keterlibatannya secara sadar dan sukarela serta terus menerus dalam berbagai kegiatan-kegiatan ilmiah, innovatif, dan keratif dalam rangkan mengembangkan profesionalismenya.

Karya Tulis Ilmiah secara ideal-fundamental berfungsi sebagai pengembangan ilmu pengetahuan, sebagai sarana komunikasi akademik dalam sebuah bidang kajian keilmuan, dan pengetahuan sehingga ditemukan runtutan (sanat) atau mata rantai keilmuan. Selain fungsi ideal-fundamental tersebut, juga terdapat fungsi praktis-pragmatis bagi profesi pendidik (guru). Fungsi ini berkait dengan karir dan kepangkatan guru sebagai tenaga profesiona dan bertujuan untuk membina karier kepangkatan dan profesionalisme guru. Karya ilmiah yang dipublikasikan adalah bagian dari kredit atau poin penilaian pada bagian pengembangan keprofesian berkelanjutan guru. Hal ini sebagaimana diatur dalam Peraturan Menteri Negara Pendayagunaan Aparatur Negara dan Reformasi Birokrasi Nomor 16 Tahun 2009 Tentang Jabatan Fungsional Guru dan Angka Kreditnya.

Karya tulis ilmiah ini merupakan bagian dari kegiatan Peningkatan Keprofesional Guru. Dijelaskan dalam buku pedoman Pembinaan dan Pengembangan Profesi Guru disebutkan bahwa Pengembangan Keprofesian Berkelanjutan (PKB) dilakukan melalui pendekatan yang diawali dengan perencanaan untuk mencapai standar kompetensi profesi (khususnya bagi guru yang belum mencapai standar kompetensi sesuai dengan hasil penilaian kinerja, atau dengan kata lain berkinerja rendah), mempertahankan/ menjaga dan mengembangkan pengetahuan, keterampilan dan perolehan pengetahuan dan keterampilan baru. PKB dalam rangka pengembangan pengetahuan dan keterampilan merupakan tanggung-jawab guru secara individu sesuai dengan masyarakat pembelajar, jadi sangat penting bagi guru yang berada di ujung paling depan pendidikan. Oleh karena itu, agar PKB dapat mendukung kebutuhan individu dan meningkatkan praktik-praktik keprofesianalan maka kegiatan PKB harus: (1) menjamin kedalaman pengetahuan terkait dengan materi ajar yang diampu, (2) menyajikan landasan yang kuat tentang metodologi pembelaran (pedagogik) untuk mata pelajaran tertentu, (3) menyediakan pengetahuan yang lebih umum tentang prosespembelajaran dan sekolah sebagai institusi di samping pengetahuan terkait dengan materi ajar yang diampu dan metodologi pembelaran (pedagogik) untuk mata pelajaran tertentu, (4) mengakar dan merefleksikan penelitian terbaik yang ada dalam bidang pendidikan, (5) berkontribusi terhadap pengukuran peningkatan keberhasilan peserta didik dalam belajarnya,(6) membuat guru secara intelektual terhubung dengan ide-ide dan sumberdaya yang ada, (7) menyediakan waktu yang cukup, dukungan dan sumberdaya bagi guru agar mampu menguasai isi materi belajadan pedagogi serta mengintegrasikan dalam praktik-praktik pembelajaran sehari-hari, (8) didesain oleh perwakilan dari mereka-mereka yang akan berpartisipasi dalam kegiatan PKB bekerjasama dengan para ahli dalam bidangnya;mencaku berbagai bentuk kegiatan termasuk beberapa kegiatan yang mungkin belum terpikirkan sebelumnya sesuai dengan kondisi dan kebutuhan saat itu. Di titik itu kepiawaian dan komitmen para guru dalam menulis karya ilmiah menjadi penting. Urgensinya terutama terkait peran fundamental mereka sebagai "guru kehidupan" kemana para subjek didik dan juga masyarakat luas menyandarkan sumber pengetahuannya. Guru adalah subjek aktif dalam pengembangan keilmuan dan karena 
itu pendidikan harus lebih dimaknai sebagai praksis pengayaan keilmuan di mana keterampilan menulis mutlak dimiliki sebagai media pemerkayanya.

Pada tahap ini, aksi-aksi pendidikan dan pelatihan penulisan karya ilmiah melalui pendekatan andragogis serta pendampingan berpola pembimbingan penulisan, misalnya klinik penulisan, secara intensif dilakukan dan difasilitasi oleh tim pengabdian sesuai dengan jenis program yang sudah disepakati bersama. Seluruh proses ini dikawal dengan cara pendampingan (asistensi) hingga hingga ke tahap penerbitan di jurnal ilmiah maupun media massa lokal atau tahap pengunggahan ( up load) di dunia maya.

Seorang guru akan mengetahui model-model terbaru dalam bidang pembelajaran atau disiplin ilmu tertentu jika membaca literatur, jurnal ilmiah, hasil penelitian terpublikasi,atau berbagai sumber. Begitu juga jika seorang pendidik (guru) mempublikasikan temuannya dari hasil kajian atau penelitiannya, maka guru yang lain akan mengetahui hasil penelitian guru tersebut dan dapat memanfaatkan, mengembangkan atau mendiskusikan mendialogkan dengan realitas yang dihadapi guru tersebut. Suharjono menjelaskan fungsi lain karya tulis ilmiah yaitu karya ilmiah sebagai fungsi ekpresif dan fungsi instrumental.

Fungsi ekspresif berkaitan dengan kebebasan seseorang untuk menuangkan berbagai ide dan gagasan tertulis yang dikomunikasikan kepada pihak lain. Fungsi ekspresif berkait dengan kebuthan seorang ilmuah, akademisi, dan profesional dalam upaya pemenuhan kebutuhan diri seseorang sebagai ilmuwan atau sebagai manusia yang berpikir. Sedangkan fungsi instrumental adalah fungsi pemenuhan kebutuhan-kebutuan praktis dalam rangka meraih tujuan-tujuan tertentu. Menulis karya ilmiah sebagai fungsi ekspresif-komunikatif meliputi fungsi sosial. Menulis atau berkarya merupakan wujud eksistensi dan menentukan citra diri seseorang ilmuwan atau akademisi.

Selain hal tersebut, menulis karya ilmiah juga merupakan kebanggaan, sebab kemampuan menulis karya ilmiah merupakan kemampun tingkat tinggi, yang didapat dari proses latihan, dan pembiasaan terus-menerus. Akhir dari sebuah karya ilmiah adalah dikonsumsi (dibaca), dan dirujuk (citation) oleh civitas akademik sehingga menandakan reputasi seorang ilmuan. Fungsi ekspresi Menulis merupakan media untuk mengekspresikan pikiran, ide, gagasan, imajinasi penulis. Melalui tulisan, para penulis bisa menyampaikan berbagai hal yang mungkin tidak dapat disampaikan melalui ucapan/kata-kata. Melalui tulisan pula seseorang bisa mengetahui pikiran dan perasaan orang lain.

Fungsi dokumentatif. Menuliskan ide, gagasan, renungan, dan imajinasi merupakan upaya dokumentasi yang dengan hal itu dapat diketahui, dibaca, dan diteliti sehingga diketahui jejak atau peristiwa-peristiwa tertentu. Sebuah karya tulis yang terdokumentasi juga dapat menjadi petunjuk mengenai rentetan tertentu. Fungsi instrumental. Menulis juga bisa menjadi alat untuk mengubah sesuatu (informasi, sikap, pendapat, pandangan) seseorang terhadap sesuatu. Seseorang yang semula berpandangan negatif terhadap sebuah persoalan, sangat mungkin akan berubah ketika membaca sebuah tulisan tentang sebuah persoalan tersebut yang ditulis secara ilmiah, berdasarkan data dan fakta yang valid atas dasar penelitian. 
Seseorang yang memiliki sikap jahat mungkin saja sadar akan perbuatannya setelah membaca sebuah buku keagamaan, dan lain- lain.

Karya tulis ilmiah dilihat dari bentuk penyajiannya (bahasa) dan kajiannya secara garis besar dapat dibedakan menjadi dua macam yaitu pertama, karya ilmiah kependidikan (kalangan akademisi) dan kedua, karya ilmiah penelitian. Karya imiah kependidikan adalah karya ilmiah yang disusun secara ilmiah dan mengikuti teknis penyusunan dan aturan yang umumnya difahami oleh kalangan akademisi. Karya ilmiah kependidikan ini umumnya menjadi syarat untuk meraih gelar kesarjaan tertentu. Jenis karya ilmiah kependidikan ini juga dapat dibedakan menjadi tiga yaitu (1) karya tulis kesarjanaa seperti paper atau makalah, anotasi bibliografi, book review, skripsi, tesis, dan disertasi, (2) karya tulis didaktik seperti buku ajar perkuliahan, diktat, buku teks pelajaran, dan (3) karya tulis referensi seperti kamus, dan ensiklopedi.

Karya tulis ilmiah penelitian adalah karya ilmiah yang disusun dalam rangka menjawab sebuah persoalan atau masalah. Karya ilmiah penelitian ini umumnya tidak terkait dengan syarat kesarjanaan tertentu, akan tetapi merupakan kerja-kerja imuwan, intelektual, dan profesional. Gaya penulisannya pun tidak diatur secara ketat, umumnya menggunakan bahasa ilmiah-populer dan familiar. Pilihan terhadap guru sebagai subjek atau stake holder utama program pengabdian ini bertolak dari satu postulat bahwa segala upaya peningkatan kualitas pendidikan haruslah dimulai dari peningkatan kualitas para tenaga pendidiknya ${ }^{7}$. Itulah mengapa usulan program pengabdian ini terutama menyasar para guru mengingat mustahil meningkatkan kualitas pendidikan jika tidak dimulai dari meningkatkan kualitas para tenaga pendidiknya, termasuk kualitas dalam hal penguatan keterampilan mereka dalam penulisan karya ilmiah.

\section{Kesimpulan}

Berdasarkan hasil dari pengabdian yang penulis lakukan tentang Bagaimana cara menumbuhkan minat dan pontensi guru dalam penulisan karya ilmiyah di Madrasah Aliyah Miftahul Ishlah Tembelok, dapat disimpulkan sebagai berikut: Pelaksanaan pelatihan pengembangan minat dan potensi guru dalam menulis karya ilmiah terlaksana dengan baik. (2) Hasil dari pelatihan ini tumbuhnya semangat dan minat guru dalam menulis karya ilmiah terbukti dengan berhasilnya membuat tulisan ilmiah dalam bentuk buku sederhana.

\section{Referensi}

Abd. Rachman Assegaf, Filsafat Pendidikan Islam: Paradigma Baru Pendidikan Hadhari Berbasis Integratif-Interkonektif (Jakarta: RajaGrafindo Persada, 2011), $19-24$.

Abdullah Faishol, dkk., Metode dan Te knik Kuliah Kerja Nyata Transformatif: Implementasi Participatory Action Research (PAR) \& Participatory Rural Appraisal (PRA) untuk Aksi Perubahan Sosial (Surakarta: P3M STAIN Surakarta, 2006), 117-26.

M. Taufik, Kreativitas: Jalan Baru Pendidikan Islam (Mataram: Leppim IAIN Mataram, 2012), 21-37. Suryadharma Ali, Mengawal Tradisi, Meraih Prestasi: Inovasi dan Aksi Pendidikan Islam (Malang: UIN-Maliki Press, 2013), 184-7.

Terence W. Moore, Philosophy of Education: An Introduction (London: Routledge \&Kegan Paul, 2010), 11-14.

\footnotetext{
7 Postulat ini bertumpu pada peran "profetik" guru sebagai ujung tombak pendidikan. Lihat Suryadharma Ali, Mengawal Tradisi, Meraih Prestasi: Inovasi dan Aksi Pendidikan Islam (Malang: UIN-Maliki Press, 2013), 184-7.
} 